\title{
Diaspora Identities: Jewish Bakeries and Baked Goods in London and Berlin
}

\section{Devorah Romanek}

\section{(2) OpenEdition}

\section{Journals}

\section{Electronic version}

URL: http://journals.openedition.org/transtexts/249

DOI: $10.4000 /$ transtexts.249

ISSN: 2105-2549

\section{Publisher}

Gregory B. Lee

\section{Printed version}

Date of publication: 1 December 2008

Number of pages: 48-63

ISSN: 1771-2084

\section{Electronic reference}




\title{
Diaspora Identities: \\ Jewish Bakeries and Baked Goods in London and Berlin
}

\author{
DEVORAH ROMANEK
}

This essay investigates how material culture acts as an agent of cultural construction when social and cultural practices are geographically displaced. It does this by taking a comparative look at current Jewish Diaspora communities in London and Berlin, and by analyzing the production, consumption and broader meaning of three Jewish baked goods - matzos, challah and bagels - in the context of Diaspora communities in these two cities.

The comparison between London and Berlin also allows a consideration of the construction of 'locality'/'setting', particularly in the transient sense of a fluid concept of sense-of-place as constructed against a backdrop of material culture; additionally, the level of religious observance; the contrast of notions of 'fixed' and 'fluid', and 'traditional' and 'cosmopolitan'; and the agency of the baked goods themselves is observed and analyzed.

\section{Introduction}

Anthropological discussions on the theme of cultures in movement, that is to say Diaspora, or the more contemporary notions of globalization and transnationalism, offer many disparate theories. There is the argument that globalization as a postmodern phenomenon is bringing an end to the practice of 'tradition' and 'traditional cultures', and that it is inviting a worldwide culture of heterogeneity. ${ }^{1}$

\footnotetext{
${ }^{1}$ For a discussion of this see Anthony Giddens, "Living in a post-traditional society", in Ulrich Beck, Reflexive Modernization: Politics, Tradition and Aesthetics in the Modern Social Order, Cambridge, Polity Press, 1994.
} 
There is the counter-argument that the pressure or threat (perceived or real) felt by various communities and cultures against their 'traditional' ways has induced a counter-reaction, which is being expressed in renewed and intensified forms of nationalism, and increasingly more delineated and defined concepts of self and community. ${ }^{2} \mathrm{~A}$ third argument states that the human narrative is a 'mobile resource' and that people in flux and movement are searching for their identities. ${ }^{3}$ Most anthropological theories regarding these issues tend to see the construction of identity as either fixed or fluid. ${ }^{4}$ This paper investigates what happens when material culture practices are displaced over a long period of time in Diaspora, and the ways in which the mechanisms of displacement might engender a response that is both fixed and fluid. It also tackles the question of whether material culture, rather than 'place' and 'location', can provide the 'sequence of explanatory links' that form the foundation of cultural identity for people in Diaspora, even as material culture itself can be mutable. ${ }^{5}$ These issues and questions are investigated through fieldwork research conducted in 2006, which took a comparative look at current Jewish Diaspora communities in London and Berlin.

Jews have been moving in Diaspora for thousands of years, and they have lived in every corner of the world. The material culture of the Jews in Diaspora, however, has endured even as it has changed and evolved. The three kinds of bread that form the basis of investigation in this paper - matzos, challahs and bagels - all have long and complicated histories that reflect consistencies and changes as related to practices within the Jewish Diaspora. The types of bread are 'biographical', and not simply historical, in the sense that "...objects are biographical...because they help organize personal identity, giving it some of their unity and coherence." 6 The consistencies within the evolution of these kinds of bread tell the story of fixed practices of religious rituals, family traditions, etc. The changes within the 'biographies' tell the story of the changing contexts of these Diaspora communities

\footnotetext{
${ }^{2}$ For a discussion of this see M. Kearny, "The Local and the Global: The Anthropology of Globalization and Transnationalism", Annual Review of Anthropology, Vol. 24, pp. 547-565, 1995, p. 550.

${ }^{3}$ For a discussion of this see Nigel Rapport and Andrew Dawson (eds.), Migrants of Identity: Perceptions of Home in a World of Movement, Oxford, Berg, 1998.

${ }^{4}$ For a discussion of this see Paul Basu, "Hunting down home: reflections on homeland and the search for identity in the Scottish Diaspora", in Barbara Bender and Margot Winer (eds.), Contested landscapes: movement, exile and place, Oxford, Berg, 2001.

5 "As an alternative to the metaphysics of 'race', nation, and bounded culture coded into the body, diaspora is a concept that problematizes the cultural and historical mechanics of belonging. It disrupts the fundamental power of territory to determine identity by breaking the simple sequence of explanatory links between place, location, and consciousness." Paul Gilroy, Between Camps: Nations, Cultures and the Allure of Race, London, Penguin, 2001, p. 123.

${ }^{6}$ Webb Keane, "The Materiality and Locality of Everyday Lives", Indonesia, Vol. 68 (Oct.), pp. 178 - 186, 1999, p.181. The quote is commentary by Keane on a book by Hoskins, 1999.
} 


\section{Devorah Romanek}

in flux: name changes, recipe changes, changes in significance as a product associated with particular communities and localities in the Diaspora, etc. Despite the changes and variations these goods have experienced, they form part of the material culture basis which constitutes, at least in part, the underlying 'structure of feeling' - which in turn constitutes the 'constructed locality' of Jews in Diaspora.7 The 'structure of feeling' of Jews in Diaspora is based on the fixity provided by their enduring material culture. It is this 'fixity' of the material culture that allows for and facilitates - a development of the concepts of self and culture within a reality that is more 'fluid', changing and in motion. "Diaspora is an especially valuable idea because it points towards a more refined and wieldier sense of culture than the characteristic notions of rootedness." 8

\section{Why Bread?}

Since the time of its discovery, some 6,000 years ago, bread has served as a type of staple food in many if not most cultures.${ }^{9}$ The general ubiquity of bread across cultures indicates that it is generally both easily produced and a useful product. Bread - from the making to the consumption of it, plus all that happens in between - has also served as a medium for expression, be it literal, symbolic, religious, metaphorical, personal or cultural. The usefulness of bread has to do with the agency of bread, in other words what it is inherently capable of doing. ${ }^{10}$ Bread can include many meanings, because it is capable of doing so much for the world. ${ }^{11}$ Much of what it is capable of doing is related to its inherent properties, its agency "...the kind of potential that originates not in human initiative, but instead results from the very disposition of things." 12 The fact that bread is abundant and easy to

\footnotetext{
7 “The many displaced, deterritorialized, and transient populations that constitute today's ethnoscapes are engaged in construction of locality, as a structure of feeling..." Arjun Appadurai, Modernity at Large: Cultural Dimensions of Globalization, Minneapolis, Minnesota, University of Minnesota Press, 1996, p. 199. I am also using the notion of a 'structure of feeling' in a way that it could be understood as something like Bourdieu's concept of the 'habitus', a person's disposition as the product of their subjective experience of an objective world. Pierre Bourdieu, Outline of a Theory of Practice, trans. by Richard Nice, Cambridge, Cambridge University Press, 1977.

${ }^{8}$ Gilroy, Between Camps, p. 122.

${ }_{9}^{9}$ An article on the archaeological excavation of two bakeries in Giza Egypt, offers insights into the pyramid builder's diet. AERA website, 2006, “The Lost City: Feeding Pyramid Workers" $<$ http://www.aeraweb.org/lost_city_bakeries.asp>, accessed 13 June, 2008.

${ }^{10}$ For a discussion of this notion of 'agency', wherein objects themselves possess agency, see: Alfred Gell, Art and Agency: Towards an Anthropological Theory, Oxford, Clarendon Press, 1998.

11 "...things are significant in relation not so much to what they mean in the world (the structuralist and semiotic position) as to what they do." Chris Tilley (ed.), Handbook of Material Culture, London, SAGE, 2006, p. 10.

${ }^{12}$ François Jullien, The Propensity of Things: Toward a History of Efficacy in China, trans. from the French by
} 
produce, forms the basis of its nature as a staple product. Consequently, being a staple product allows it to be available for the investment of cultural meaning. It is, however, the agency of bread - its particular properties - that enables it to be used as a metaphor, and to be imbued with symbolic and cultural meanings.

The process of bread making, when considered from beginning to end, goes through many stages: from seed to plant, from plant to harvested stalk, from stalk to threshed kernels, from threshed kernels to ground flour, from ground flour - in combination with other ingredients - to mixed raw dough, from mixed raw dough to fermented raw dough (in the case of leavened bread), from raw dough - into an oven, and then out of an oven - to cooked bread. ${ }^{13}$ This process of multiple transformations makes bread an excellent source for metaphors and symbolic meanings. These transformative processes also imply binary oppositions (for instance: raw/cooked) through which a structuralist reading of the 'deep structure' of bread myths, meanings and metaphors could be acknowledged. ${ }^{14}$ It is not just the binary oppositions and transformations present in the process of making bread that make it such an apt medium for metaphors, but also the ways in which it is homologous with other objects and processes. The process where one form (dough) leads to another (cooked loaf), offers a basis for a metaphor of the cycle of life. The cycle of making bread can be 'like' the cycle of life, just as bread can be 'like' a living body. ${ }^{15}$

\section{Matzos, Challahs and Bagels}

These three types of bread where selected in this study because they represent and are part of the construction of different aspects of Jewish life: the specifically religious aspect (matzos, also known as the 'bread of affliction', is eaten during the observance of Passover and is one of only two foods specifically described and prescribed in the Old Testament) ${ }^{16}$; the domestic and religious aspect (challahs,

\footnotetext{
Janet Lloyd, Brooklyn, Zone books, 1995, p. 13.

13 "the raw to the cooked": Claude Levi-Strauss, The Raw and the Cooked, transl. from French by John and Doreen Weightman, Harmondsworth, Penguin, 1986.

${ }^{14}$ Here I am referencing Claude Levi Strauss's theories on structuralism related to analysis of myth, and food. See Levi-Strauss.

${ }^{15}$ An obvious example of bread as body can be found in the Catholic concept of transubstantiation, which expresses that through the Eucharist the bread of communion becomes the actual body of Jesus Christ: "While they were eating, Jesus took bread, gave thanks and broke it, and gave it to his disciples, saying, 'Take it; this is my body'. New Testament Bible: Mark 14:22-24.

16 The two types of food prescribed in the Old Testament are the special meal for Shabbat - called cholent by the Ashkenazim or chamin by the Sephardim - and matzos, which are to be eaten during Passover in commemoration of the flight of the Jews from slavery in Egypt. No leavened bread (hametz) is to be eaten during Passover, which is why matzos are a mix of flour and water that is not allowed to ferment or rise.
} 


\section{Devorah Romanek}

usually braided loaves of bread, traditionally eaten at home every Friday night to celebrate the Sabbath,); and finally the secular/cosmopolitan aspect. To define this last aspect I will refer to bagels. The origins of bagels are somewhat vague, but it is generally understood they originated in Eastern Europe, and 'bagel' is known in Yiddish as 'beigel', a bread ring that is usually first boiled and then baked. Informants interviewed used all these products, although in differing ways, to differentiate themselves from others in order to distinguish who they were, as opposed to who they were not. Interviewees also mentioned all three types of bread in the speaking process, to make a statement about the relationship to their identity as Jews, to their Jewish community, to other Jewish communities, or to the outside world. Food, its making, ritual use and consumption, is a foundational structure in Judaism, in that it creates the endogamous base of Judaism. Although the prohibition on eating pork in keeping kosher is perhaps the most discussed aspect of Jewish relationships to food ${ }^{17}$, bread forms the basis of many Jewish rituals matzos on Passover, bread crumbs on Rosh Hashana, challahs on the Sabbath, and bread as the focus of all meal time prayers. ${ }^{18}$ Insider knowledge of what these varieties of bread 'mean', or more importantly what they 'do', enables people to see themselves as Jewish, and/or as belonging to a Jewish community. In this sense, these types of bread may serve as a framework for knowledge and community/selfunderstanding, or as a means used to communicate and represent these concepts.

\section{Who is Jewish?}

The research carried out for this paper was conducted in Jewish communities in London and Berlin, focusing on bakeries and stores where these bread products

\footnotetext{
${ }^{17}$ E.g. Mary Douglas's analysis of the pork taboo in Jewish religious law, or Richard Lobban Jr. and Joelle Bahloul. Mary Douglas, Purity and Danger: an Analysis of Concept of Pollution and Taboo, London, Routledge, 2002. Richard Jr Lobban, "Pigs and Their Prohibition", International Journal of Middle East Studies, Vol. 26, n¹. (Feb.), pp. 57-75, 1994. Joelle Bahloul, “Food Practices among Sephardic Immigrants in Contemporary France: Dietary Laws in Urban Society", Journal of the American Academy of Religion, Vol. 63, n³, Thematic Issue on "Religion and Food", (Autumn), pp. 485-496, 1995.

Note on the word Kosher: this refers to the larger concept of Kashruth, which is the corpus of Jewish dietary codes or laws. These laws come from the wider code of Jewish law known as the Halakha. "Perhaps the most fundamental division of material things into categories of holy and profane arose from the Jewish dietary code. Based on scriptural passages and on Talmudic interpretations of those passages, the concept of kashruth, or ritual fitness, generated an elaborate system of prohibited and permitted foods." Andrew R. Heinze, Adapting to Abundance: Jewish Immigrants, Mass Consumption, and the Search for American Identity, New York, Columbia University Press, 1990, p. 53.

18 The prayer before a meal is called Motzi or Ha-Motzi, which is actually a prayer said over bread, as eating is not considered a meal unless there is bread. The prayer after a meal is called Birkat Hamazon, which is a collection of blessings that are part of Halakha that are recited after any meal with bread made from wheat, spelt, oats, rye or barley. The bread may be leavened or unleavened.
} 
could be purchased, but some interviews were also conducted in the homes of some interviewees. Informants with a mixed background were amongst those interviewed. Mixed backgrounds related to age, gender, income and religious observance. In approaching the topic, it was important to identify and define what was meant by 'Jewish' in relation to the Jewish Diaspora. For the purposes of this paper, Jewish informants were self-identified as such. However some informants were not Jewish, or did not self-identify as Jewish. The non-Jewish informants fell into two categories. The first category consisted of non-Jews who do not selfidentify as Jewish and would not be considered Jewish by others, that is to say, people without any Jewish heritage. These non-Jewish informants were interviewed because they did something in their lives that was relevant to the topic (they were academics in this area, or worked in the baked products industry or related fields, etc.). The second category of non-Jewish informants was formed by people who did not self-identify as Jewish, although they would potentially be identified by others as Jewish (i.e. having Jewish heritage, specifically Jewish mothers). For many of mixed heritage, there was an ambivalence regarding their identity, but this was also connected to whether they lived in London or in Berlin. Interviewees of mixed heritage in London tended to be less ambivalent, and more likely to strongly identify as Jewish, compared to those of mixed heritage living in Berlin. The fact that some Berlin informants distanced themselves from their Jewish identity is reflective of the dramatic rupture in Jewish presence and identity in Germany as a whole. This was a central factor in the differences between circumstances in London and Berlin as revealed through the fieldwork. In addition to the city the informants lived in, religious ties and practices seemed to be another leading factor in how informants related to the types of bread.

\section{London and Berlin: a Comparative Look}

Each variety of bread will be discussed individually, but firstly it is necessary to give an informative overview of the context in which the fieldwork took place, i.e. the comparison between London and Berlin. The overall Jewish community in London is larger in number than the Berlin Jewish community. There is also some historical continuity to the communities in London compared to those in Berlin, due to the legacy of the Second World War. The violent break in continuity in Berlin compared to the relative continuity in London played out in one way or another in the relationships informants had with all the baked products, and all the contexts surrounding the types of bread. In both London and Berlin there were differences in the interviewees' responses that had to do with their religious background. Orthodox, Reform Jews and non-religious members all had different things to say. 


\section{Devorah Romanek}

Taking each city's Jewish community as a whole, there was an obvious difference of character between the two cities. The broader London community seemed to be able to absorb without too much trouble the impact of differences and conflicts that existed between various Jewish communities, while these differences in Berlin were contentious, and tension was obvious. ${ }^{19}$ Some understanding of these differences is summed up in an excerpt from an interview with a Jewish survivor of the Shoah, who now lives in Berlin. The excerpt is from the book Jüdische Berliner: Leben nach der Schoa (Jewish Berliners: Life after the Shoah):

"I think that the Jewish community is simply too small. The percentage of Jews in Germany is tiny. Berlin has the largest community with just over 12,000 Jews. In 1937 it was 181,000. In 1937 in Germany there were 734,000 Jews. Today there are 100,000 . Out of that perhaps 70,000 are Russian speaking Jews.... Who really knows anything about Jewish holidays today? ... Today, when someone simply wants to go to a Catholic church... they simply go in... But you don't simply go into a Synagogue. And that has something to do with security issues also... The armed police before the door...that deters people.

It was different before the war; every good German businessman knew when the Jewish holidays were. Every German businessman that had dealings with Jewish businesses had his own Kipa ${ }^{20}$....When he went to visit a Fromm Jewish family he did not have to borrow one. People knew what was what. That is how it is today in London. In London today there are only about 400,000 Jews, but the people who are in daily contact with Jews know something about Jewish beliefs. They acquire this knowledge out of interest, and so they don't have to feel uncomfortable." 21

\section{Findings on Matzos}

Matzos represent the traditional 'bread of affliction'. They are called so because they used to commemorate the exodus from Egypt and the suffering of the Jews. They are a form of unleavened bread that is rolled out very thin, perforated very densely and baked - in fact, they are much like very plain crackers in appearance and consistency, although their appearance can vary, as more traditional versions

\footnotetext{
${ }^{19}$ At the time research was undertaken, there was no Beth Din in Berlin( the religious judicial body in the Jewish community, which typically has oversight of governing religious matters, including matters of Halekha and therefore also kashrut or kosher), and one kosher bakery owned by a protestant baker, and one Jewish owned baker/bakery who made kosher-style baked goods, as the owner did not wish to deal with the Orthodox Rabbi who was issuing the kosher certificate - a contentious situation.

${ }^{20} \mathrm{~A}$ Kipa, also known as a yarmulke, is a round type of head cover worn by observant Jewish men.

${ }^{21}$ Interview with Manfred Alpern in: Ulrich Eckhardt and Andreas Nachama, Jüdische Berliner: Leben nach der Schoa, Berlin, Jaron Verlag GmbH, 2003, pp. 33-34; translated from German by the author of this paper.
} 
tended to be round, while more recent versions are square. The responses of informants in Berlin and London regarding matzos were not that different. This was the type of Jewish bread that produced greatest consistency amongst all interviewees, regardless of their city or level of religious observance. The most important thing to informants who considered this bread significant was its role in observing Passover. Furthermore what emerged was that even if the informants did not consider themselves religious, they argued matzos should be "kosher for Passover". ${ }^{22}$

The greatest indicator related to differentiation in responses regarding matzos was gender, with women having much more to say about the topic than men, and women being the greatest consumers of matzos (both in terms of buying and eating). The manner of consumption of informants from London and Berlin was nearly identical - matzos are usually eaten with butter. Any variations on the manner of consumption tended to be specific to the city/country the informant lived in. For example the German variation is with butter and honey. ${ }^{23}$ The other difference in responses was related to brand. In London, an overwhelming majority of informants ate Rakusin's, which is made in Leeds, or Yehuda's, which is made in Jerusalem, creating a balance between one domestic brand and an imported brand. In the kosher shops in Berlin, all products were imported. The only domestic brand of matzos sold in Berlin, P. Heumman, which is sold at mainstream supermarkets, is marketed as a diet product. Rakusen's in London also targets diet cracker consumers, but some types are clearly promoted for a Jewish market, or a market that may or may not be Jewish, but wants to buy Jewish crackers. There are a number of possible factors involved in the variations of brands available in the two cities, but the marketing of matzos as diet crackers is reflective of the phenomenon of either perceiving or presenting 'Jewish' food as a general notion - specifically kosher Jewish food - as 'healthier' and 'cleaner'. This phenomenon was commented upon by a number of Berlin interviewees, mostly owners of Jewish or Kosher shops. One owner of a 'Jewish-style' bagel bakery in Berlin said that many of her customers are "interested in eating vegetarian, and in eating things that are fresh and healthy." The kosher baker in Berlin also commented that his "...bread is pareve, so (for that reason) many vegetarians and vegans like it." 24

\footnotetext{
${ }^{22}$ Keeping kosher for Passover is different from daily kosher practices. It includes the prohibition on eating leavened breads, among other things. See footnote 17 for a definition of kosher.

${ }^{23}$ Eating butter and honey on bread or a roll is a very typical German breakfast. Interesting to note, one informant in London, who is actually Dutch and not Jewish, but does eat matzos, eats them around "Easter time," which is also around Passover and when they would be available for sale in the Netherlands. She eats them with butter and sugar. It would be interesting to follow similar patterns of consumption and variation around the world (where it would be applicable).

${ }^{24}$ Pareve is an aspect of Kosher, according to which the food does not contain any animal products
} 


\section{Devorah Romanek}

Clearly the matzo type of bread is ritually and symbolically significant in relation to the Jewish identity, but it does not typically serve as a regular part of creating and maintaining identity for most informants. The Jewish interviewees who ate matzos in any regular way were all women, except for one man who ate them as diet crackers, but this level of consumption did not compare to the overall consumption of the other two types of bread. The level of consumption of matzos was also the lowest out of all the varieties of bread for non-Jewish informants. Matzos were always bought pre-packaged, and they were generally not associated with a specific baker, bakery or store. It is worth noting though, that for some Berlin Jewish informants it was appealing to buy matzos made in Israel because it allowed them to feel some connection to Israel. For some, particularly women, matzos serve as a way to consume other products such as butter. Others, on the other hand, consume matzos as diet crackers. However, the role of matzos in the annual festival of remembrance, Passover, proved its key function in strengthening the Jewish identity, and the more religious aspects of this identity. The importance of its status as "kosher for Passover" was its most frequently mentioned feature. As the bread of annual remembrance, matzos function as something like a symbol, as part of the “...social dynamics of remembrance and commemoration defined by a strong sense of the dangers involved in forgetting the origin and the tearful process of dispersal." 25

\section{Findings on Challahs}

Challahs, which could be called 'the bread of differentiation' (although, as previously stated, all the types of bread were used to imply distinction) constituted the variety of bread which was discussed the most. However, it must be noted that challahs do not necessarily serve this function for the most assimilated and nonreligious informants, who related at least as much to bagels. In any case, just like matzos, the reasons challahs play the role that they do are many - historical and practical. Nonetheless this also has to do with the agency of the bread itself, and the inherent properties of a loaf of challah. Challahs were the most sensuously described by informants. Informants described the richness of challahs, and the decorative nature of the product: "challahs have lots of egg in them." "Challahs are

\footnotetext{
including dairy. This also includes everything that was used in the making of pareve food. The utensils for example don't come into contact with animal products. For further discussions on the phenomenon of the marketing of foods as Jewish/kosher or Jewish/kosher-style food as healthy and clean foods see: Ruth Gruber, Virtually Jewish: Reinventing Jewish Culture in Europe, Berkeley, London, University of California Press 2002, p.6; and Eve Jochnowitz, "Flavors of Memory: Jewish Food and Culinary Tourism in Poland", http://www.nyu.edu/classes/bkg/poland.eve.

${ }^{25}$ Gilroy, Between Camps, p. 124
} 
fancier, a richer type of bread, with egg, decorated in different ways and at different times of the year for different holidays." "Challahs are very rich in taste, with the right degree of chewiness." "Challahs can be decorated in so many ways, with different types of braiding, and different shapes...long, or round like for Rosh Hashanah." 26 "We sell four different types of challahs: one is normal and one is sweet with poppy seeds, so we have a large variety of these kinds and also a small variety, for people who just want a challah for themselves."

The fact that challahs are rich in taste and typically sweet, and sometimes elaborately decorated is part of what enabled informants to identify with this variety of bread as something special and meaningful. Furthermore, because this was the bread most often made at home, people had memories or stories about it being made, which additionally increased the meaning of the bread to interviewees. Also, even if challahs were not made at home, informants still felt connected to the baking process having established a relationship with their bakery. The greatest amount of bakery loyalty was related to the purchase of challahs, more than to bagels, and this was so both in London and Berlin. All the informants, whether in London or Berlin, could name the bakery where they regularly bought challahs (if they were regular buyers), and they seldom bought challahs elsewhere. One informant who lives in South London said that her husband will detour out of his way for the 'best' challahs, which come from an Israeli bakery (not kosher) in the West End. In Berlin the notion of bakery loyalty was even stronger, having much to do with differences in community ties through levels of religious observance as well as with the previous division of Berlin between East and West. For many, one of the most significant connections between challahs and informants was the formal and religious rituals associated with the bread. It is important to note the use of the phrase 'formal and religious' because some of the other usual activities associated with the bread that informants engaged in - buying regularly from the same bakery, buying at the same time of the week every week, at the same time of day every week, etc. - could be considered 'ritualistic'. The formal and religious rituals associated with challahs include the separation of challahs from the dough, ${ }^{27}$ the prayer over the bread - Motzi - associated with the Kiddush in general, the

\footnotetext{
${ }^{26}$ Rosh Hashanah is the Jewish 'New Year' (of four New Year celebrations in Judaism) and one of the most important holidays. One of the rituals of Rosh Hashanah is called tashlich, which involves casting bread crumbs into moving waters as a way to symbolically cast away sins as an act of atonement. Sometimes the bread crumbs that are cast are left over pieces of the Passover Afikoman, which serves as a link between the holidays.

27 'Separating the challah from the dough' refers to the practice that is prescribed by Halakha (Jewish religious law), that dictates that a small piece of dough should be separated from the main dough that is going to be made into bread, and that this piece should be blessed and burned and discarded, as an offering. The term challah in this instance actually refers to the small piece that is to be offered.
} 


\section{Devorah Romanek}

communal breaking of the bread after reciting the Motzi, eating the broken off piece of the Sabbath challah with salt, eating additional challahs with the meal, followed by the recital of the Sabbath version of the Birkat Hamazon. ${ }^{28}$

When there is a small enough group saying the Kiddush, either around a Sabbath dinner table or in synagogues, the Motzi is recited with each person having one hand holding the challah. After this everybody breaks a piece of bread off, which is salted and eaten while still gathered in the Kiddush circle. This ritual is clearly very communal and emotional. The participants hold the bread and then eat it together. This turns the group of people gathered momentarily into one body centered around the bread, the bread therefore being the central organ of that communal body. The formation of this communal body through the bread is part of the formation of differentiation, the 'us' from 'them', those who are part of the communal body and those who are not. It is also symbolically interesting that in this ritual participants stand in a circle facing inwards. This is a literal manifestation of the way in which challah bread functions. It turns community members inward towards the community, with their backs to those on the outside - a process of differentiation, the 'wider challah eating community' differentiated from the rest. Despite its function as differentiator, challah bread may also function as a gift and as a mechanism to reach out to others, particularly because it is such a special type of bread, embellished and very rich in taste. Even when it is given as a gift, or when those who might normally stand outside the circle are invited in to participate (i.e. invited to a Sabbath meal) they still are on the outside, because their relationship to and knowledge of the bread is different.

\section{Findings on Bagels}

Amongst the three breads in Diaspora, bagels are perhaps the most popular worldwide. They are also symbolic because of their wheel/ring shape. The fact bagels are the most well-known type of bread amongst 'outsiders', is a reflection of how far and wide this variety has spread. It is also widespread in the sense that variations of it (including previous versions of it) are to be found under various names all over the world. ${ }^{29}$

\footnotetext{
28 The Sabbath version of the Birkat Hamazon includes an extra paragraph known as Retzei.

29 'Bagel' can be spelled and pronounced in many ways, including: beigel, beygel, beugel, and bugl. Other ring breads that could be considered related to bagels include: obwarzanki (undoubtedly the bread that Polish Jews brought with them to America, which became the universal type of bagels), bublik (Russian ring bread that is like bagels), biscocho (the bagel-like bread of the Sephardic Jews, who brought this bread with them as they dispersed around the world, including on their $15^{\text {th }}$ and $16^{\text {th }}$ Century voyages to the 'New World' and to the Philippines. Could it be that the State cookie of New Mexico, the ring cookie also known as biscocho, is indeed the descendant of that bread and related to
} 
All informants had feelings about how widespread and popular bagels are, but some addressed this directly, while others expressed anxieties about this as subtext. Bagels are not part of religious rituals, and therefore do not possess the power to induce conformity in the way that matzos and challahs do. All these factors, i.e. that bagels are cosmopolitan, universal and lacking in the structure to allow a dialectical relationship that is about conformity, made those informants who are closer to conformity (at least related to their Jewishness) uncomfortable. This resulted in these informants distancing themselves from this type of bread. One informant went so far as to indicate that bagels are not even truly Jewish. The distance from bagels of most observant informants not only took the form of how they spoke about bagels, but also of how they consumed bagels, as it was the variety of bread that the highly religious informants ate the least. This was in contrast with the least religious informants, who ate bagels more than the two other types of bread. For these informants, bagels, or 'beigels', were directly related to their identity as Jews. Therefore the more religious informants met their longing for 'home' by building 'home' into their religious practice, and through rituals involving the religious breads. On the other hand, the less religious informants met their longing for 'home' by building 'home' into the more fluid cosmopolitan notion of themselves as an ethnic expression in the midst of a varied panoply of mixed cosmopolitan ethnic expressions. This feeling of 'longing' for 'home', or longing for something that was lost, is also a longing to be - to exist as an understandable and recognizable entity. In this sense, bagels, like all types of bread, serve as a mirror reflecting identity. The difference is that the other two varieties of bread, matzos and challahs, serve more as a mirror reflecting something interior, something of a self-generating, selfperpetuating image of who one is when one is a Jew. The images matzos and challahs offer are more stable and fixed. The fluidity of meaning and possibility that these two breads provide us with is much more gradual than in the case of bagels, and cannot necessarily be noticed easily within the context and time frame of world history. Bagels also serve as a mirror, but a mirror that offers a view of oneself that tends to reflect and project outwards, out into the wider world, as opposed to back into the smaller community. Envisioning bagels as a 'mirror' of identity even offers

\footnotetext{
bagels?), nang, non or nan (the indigenous Uighurs from Xinjiang province of China make this round bagel-like bread, the earliest archaeological finds of which date back to $300 \mathrm{BC}$. Currently it is possible to buy non in a Jewish bakery catering to Bukharan Jews in Queens, New York [Brawarsky]), Ka'ak (another product similar to bagels, and which dates back to ancient Egypt. It is also possible to buy Ka'ak in Brooklyn in a store run by Egyptian Jews [Brawarsky]). Other ring breads, many of which have symbolic meanings, are found all over the world, including: Pan del Muerto and Rosca de Reyes (Mexico) Ciambella all'Anice (Italy), Tsoureki/Lambropsomo and Koulouri (Greece), Brezel (Germany), Ka'ak (Syria), Simit (Turkey), etc. See S. Brawarsky, “The Other Jewish Food: A Subway Tour of Bukharan, Yemenite and Syrian Markets in the Boroughs, from Almond Fingers to Z'hug", Jewish Week Book Critic Website: <http://www.thejewishweek.com/bottom/specialcontent.php3?artid=633>, 2003.
} 


\section{Devorah Romanek}

the possibility of a reflected image of the self to those who are not the focus of this study, to the 'others', the 'outsiders', in some interesting reversal of Simmel's 'stranger', to the non-Jews. ${ }^{30}$ This potential of bagels being a cosmopolitan mirror of multi-culturalism anchored in the Jewish identity, can be found in the following quote from a London interviewee:

"I've found it quite endearing that people take on some of Jewish Culture. I've worked a lot with refugee and asylum seeking groups, because of my background really I think. Anyway, the best form of integration is where the host culture takes on some aspect of the immigrant culture. This enriches the culture. I think it is funny to think of some conservative MP munching at a bagel as he mutters something about the 'Jews'. People don't realize, for example, when they're using Yiddish, but they do."

Similarly, another London informant asked what she thought of non-Jews making or eating Jewish types of bread, responded: "I think it's encouraging. I think multiculturalism is a good thing. I like to think of some white Brit eating their chicken Tikka Masala for dinner, and heating their bagel at lunch."

Clearly, those informants who related to bagels the most also felt more comfortable with a fluid concept of being Jewish. Nevertheless, these informants still saw themselves as possessing authoritative knowledge on what makes a bagel a 'bagel', or perhaps more accurately, a 'beigel', as some Jewish informants in London referred to bagels by their Yiddish name. This emerged in the debate on how a bagel should be cooked, what its texture should be like, whether it was proper to toast it or not, etc. ${ }^{31}$ It is interesting to note that in the case of bagels, it was the characteristics of the bread, by and large, that defined whether they were 'proper' or not. The physical features of the other two varieties of bread were also considered important, but this was especially true for bagels. Indeed, in the absence of a religious codification for bagels, their appearance is what counted the most. In London, bakeries that wished to convey their authenticity as Jewish bakeries, in addition to having kosher certificates and so on, made bagels that were smaller, baked for longer and browner than grocery store bought bagels or bagels from nonJewish bakeries. ${ }^{32}$ All of these Jewish bakery bagels were denser and crunchier than

\footnotetext{
${ }^{30}$ Georg Simmel, On Individuality and Social Forms: Selected Writings, edited and with an introduction by Donald N. Levine, Chicago, London, University of Chicago Press, 1971, pp. 145-149.

31 The debate about toasting is also covered in Mimi Sheraton's book about bialys. Mimi Sheraton, The Bialy Eaters, New York, The Random House Publishing Group, 2002.

${ }^{32}$ The notion of browner, longer cooked bread being more authentic or traditional is something that is also mentioned in Mimi Sheraton's book about the bialy. Sheraton 2002. Regarding the size of an 'authentic' bagel, the early Beigel Bakers Union of New York (founded 1907) made bagels that were about three and a half ounces. Bagels today can weigh about seven ounces. Barbara KirshenblattGimblett, a professor of performance studies at New York University who is working on the social
} 
their 'fluffy' non-Jewish counterparts. We should also consider the issue of bagel variety or type. For many informants, the bagels now on offer are simply not authentic: "...Sainsbury wholemeal bagels are nice, but it's not the same, it's not really a bagel." Even in Berlin, where bagels did not serve as a reference point for many informants, the owner of the Jewish bagel bakery stated: "Other bakeries take normal bread dough to make bagels, but that is not a proper bagel. [Our bagels] are firstly cooked in boiling water with honey, and then baked. [Our] bagels are the only proper bagels in Berlin." By contrast, the Berlin bakery with the kosher certificate made bagels (from wholewheat) that weren't cooked in water first, but only baked. The baker said that he did not boil them first because it was "too much work... [it makes them] too tough... [and]...many of my customers like them like this." The refusal to boil bagels first could also be seen, in the light of comments by informants, as a "subversive" and innovative act by the baker. ${ }^{33}$

\section{Conclusion}

Bread - matzos, challahs and bagels - as a vehicle for constructing a concept of the self, community and culture does not simply function as a symbol or sign, but is an actual agent of cultural construction. The processes involved in this construction are many, and the variables are virtually limitless. However, as the interviewees contributing to this paper clearly expressed, in the midst of the complexity of the Jewish Diaspora there are some elements that do come into focus as important factors in these processes. One of the major factors is setting, from big to small: city, neighbourhood, and 'locality'/'setting' in the transient sense of a fluid concept of sense-of-place. More specifically, it could be noted that the differences observed in environment between London and Berlin were based on this fluid notion of 'locality'/'setting' - which was in turn constructed in relation to, or from, material culture.

There is no question that bread in general is a very effective means in the construction of a sense of 'self'. This has to do with bread's universality and with its agency. Informants in this paper used all three types of bread to construct an idea of themselves as Jewish, but this was done in different ways. In addition to setting, relationships between informants and the kinds of bread tended to be informed by

\footnotetext{
history of bagels, said "The increase in size was an attempt to make a more competitive and more profitable product consistent with the supersized trend of the 1980's." Levine (ed.), "Was Life Better When the Bagel was Smaller?", The New York Times, style section, December 31, 2003.

33 Relating to the controversies in Jewish communities in Berlin, where there was also some tension around the fact that the Protestant baker who sold certified Kosher breads also sold pork sandwiches in his shop (albeit wrapped and separated from the breads), as some informants also talked about the 'subversive' nature of this.
} 


\section{Devorah Romanek}

levels of religious observance. This often translated into whether informants approached varieties of bread in a manner that was more 'traditional' or 'cosmopolitan' - whether they shared bread within a more closed and exclusive circle or within a broader community. Even for those informants whose practices and ideas were more 'traditional' and 'static', this static nature was nevertheless built upon a foundation of mutable objects, including the varieties of bread defined in this paper. The fact that the three kinds of bread are variable made it problematic for informants to control them within the urban environments that were the subject of this research - this was particularly true for bagels. The spreading of the meaning of these baked products, and their large increase in a broader urban context allowed for "...others to be a bit Jewish." 34 This process required informants, even those who had a greater interest in sharing these products, to invest in and be informed by evolving concepts and knowledge related to these baked goods in order to facilitate the process of differentiating through the varieties of bread. If, on one hand, the mutability of these baked goods proved problematic, it was also a characteristic that enabled these goods to function as a 'hedge of Jewish identity', because these products are versatile, and yet still possess certain inalienable qualities. Interviewees engaged with these baked goods at different stages, such as production and consumption, exchange and ritual. No matter at which phase informants engaged with these breads, a transformative mechanism was always involved, and in this process both subject and object were altered.

The three types of bread, in addition to serving as agents of facilitation in the process of creating a concept of self, were also used by informants to make statements, either reflexively about themselves, or as a commentary about the world. These statements were often things that could not be expressed in words or narrative, reflective of the poetic power of the agency of material things. ${ }^{35}$ Individuals and communities within the Jewish Diaspora, in engaging in creative ways with their material culture, and as a response to pressures to adapt that come with being in Diaspora, have found means to adjust to these environments, and still be Jewish. In such instances, it is not only a matter of Jews instilling the meaning of these types of bread, but rather a matter of Jews themselves being worked upon by the 'agency' of the bread. These breads, in relation to Kashruth ${ }^{36}$, can function as a

\footnotetext{
34 Professor Michael Rowlands: e-mail correspondence September 14, 2006.

35 This is an allusion to Jean-François Lyotard's postmodern rejection of grand narratives, and his embrace of the sublime power of art, which is capable of expressing the inarticulable. Here I am indicating that material culture - a loaf of bread - is capable of expressing the sublime as well, such is the potential power or agency of material objects. Jean-François Lyotard, The Postmodern Condition: $a$ Report on Knowledge, foreword by Fredric Jameson, transl. from French by Geoff Bennington and Brian Massumi, Manchester, Manchester University Press, 1984.

36 See footnote 17 for an explanation of kashruth.
} 
mnemonic memory device, reminding people of what it means to be a Jew, serving as a demarcation for either observance or transgression. ${ }^{37}$ It is not just the religious laws and rituals that are the context for what these baked goods do, but also, and just as importantly, the more unconscious secularized, but nevertheless 'ritualized' practices of making, buying, giving and/or consuming these bread products.

In addition to considering what is being created with these bread products - ideas about the self and about one's community - there is the issue of what is being denied in the making and consuming of these types of bread. There can be the denial of universal unity, the rejection of the idea that one is like the 'others', the 'others' being those who do not possess the same knowledge of these kinds of bread, and are not part of the cyclical reconstruction of knowledge in the making and consuming of the bread. Although these varieties can be used to mark differences, they may also serve as a bridge to reach out beyond these differences. They may function as an offering, a mediator, crossing boundaries, reaching out to 'others'. This 'reaching out' through these baked products may happen more casually around everyday interactions, or it may happen more formally in connection with specific Jewish holidays that are about the inclusion of 'others' ${ }^{38}$ In this way, even when viewing these types of bread from within the framework of Halakha, the parameters set on them can function differently than, for example, the kosher restriction on eating pork, which can only function as a restrictor and not a mediator. ${ }^{39}$ It is interesting to think about the etymology of the word 'company' related to this idea: 'company' comes from the Latin companio, meaning 'bread sharer' ${ }^{40}$ The idea that bread is about sharing company runs throughout this paper. The paper also covers the binary oppositional notions of 'fixed and fluid', and 'traditional and cosmopolitan'. It is a matter of whether this sharing of bread is inclusive or exclusive, whether the bread is used to reflect company kept in a closed circle, or whether it is used to mirror a wider reflection of company to be found in the broader context of the world.

\footnotetext{
37 "A mode of transmission which emphasizes the duration of objects as a mnemonic device is perhaps more familiar to heirs of a monumental built environment tradition..." Michael Rowlands, "The Role of Memory in the Transmission of Culture", World Archaeology, Vol. 25, n², Conceptions of Time and Ancient Society, (Oct.), pp. 141-151, 1993, p. 141.

${ }^{38}$ Here I am specifically referring to the Sabbath, and to the holidays Passover, Sukkoth and Tu bishevat.

${ }^{39}$ For a definition of the term Halakha, see footnote 17.

40 The Latin com- together and panis bread, from: http:/ / www.allwords.com/query.php?SearchType=3\& Keyword =companion.
} 